\title{
Review
}

\section{The Demarchy Manifesto: For better public policy. How to enlighten, articulate, and give effect to public opinion}

\author{
John Burnheim \\ Imprint Academic, Exeter, 2016, viii+143pp., \$19.90/£9.95, \\ ISBN: 978-1845408916
}

Contemporary Political Theory (2018) 17, S26-S29. https://doi.org/10.1057/s41296017-0102-6; published online 6 April 2017

The title of The Demarchy Manifesto suggests that the book will offer a passionate battle cry, seeking to rally support for some sort of political cause. And the book does indeed espouse a cause - demarchy, which appears to be both a new political system and a new way of thinking about politics. Both the political system and the way of thinking are intriguing and worth a bit of thought. But as a manifesto, the book does not succeed. The masses are unlikely to be drawn to the barricades any time soon by The Demarchy Manifesto.

Several factors work against The Demarchy Manifesto's success as a manifesto. The biggest of them is an inability to stay on target. The book opens by introducing the concept of demarchy, a concept which (following F.A. Hayek) Burnheim wishes to contrast with democracy (p. 10). But while the book opens by offering a definition of demarchy (more on that in a minute), it starts to wander almost immediately after this promising start (p. 1). Sometimes, the result of these wanderings is platitude - e.g., "Authority is most secure when the body exercising it makes its decisions on the best available evidence, using the best available decision procedures" (p. 62). Sometimes, the result is tangent - see, for example, Burnheim's suggestion that the American South should have been allowed to secede in peace on the eve of the U.S. Civil War (p. 91). (Tangents are very dangerous in a manifesto, which must, by definition, be brief and to the point.) When reading The Communist Manifesto, it is hard to forget that this is a book trying to sell its reader on the virtues of being a communist; I wish I could say the same for The Demarchy Manifesto.

The book does, of course, get around to discussing demarchy, but the result is less than satisfying. Burnheim seems to envision demarchy as both a political system and a way of thinking about politics. This is a reasonable enough thing to do - people often think about democracy in the same way, as both an ideal (rule by the

(c) 2017 Macmillan Publishers Ltd. 1470-8914 Contemporary Political Theory Vol. 17, S1, S26-S29 www.palgrave.com/journals 
people) and a set of institutions designed to realize that ideal (such as elections). At the level of political system, a demarchy "is primarily a process of transferring the initiative in formulating policy options from political parties to councils representative of the people most directly affected by those policies" (p. 1). Burnheim first introduced the idea of a system of randomly selected councils in a pair of articles published in 1981 (Burnheim, 1981a, b); he then introduced the term "demarchy" to describe this system in his book Is Democracy Possible? (1985). Burnheim's goal in these earlier works was explicitly "utopian" (p. viii), part of a call for the radical transformation of liberal capitalist democracy. But in The Demarchy Manifesto Burnheim's picture of demarchy is both less utopian and more vague. Whereas in his earlier works Burnheim was willing to detail the workings of his proposed political system - a system he envisioned as a radical alternative to the status quo - in his latest book he presents demarchy as a more constrained modification of the current system. Moreover, the details of this modification are never spelled out. Burnheim still envisions a system of councils selected through some form of random selection, but "What precise forms those councils should take is a matter that can be decided only by experience, and it is unlikely that one formula is going to fit all problems" (p. 39).

Burnheim is willing to make one commitment regarding the form that demarchy would take. The councils he envisions would have proposal power only; elected politicians would still have to turn these proposals into law. If the councils do a good job, Burnheim hopes that deferral to them might gradually take place through "convention," on analogy with the British constitution (p. 141).

Beyond this, however, Burnheim's aversion to providing institutional details in The Demarchy Manifesto is quite extreme. For example, Is Democracy Possible? makes plain that the random selection of councils is an essential part of demarchy. But in The Demarchy Manifesto Burnheim can scarcely be bothered to mention random selection at all, let alone explain why it plays such an important role in his theory. In addition, demarchic councils are not supposed to be selected via pure simple random selection from the general population; rather, they are supposed to be selected so as to be "representative of the people most directly affected by those policies." But what exactly does that mean? How will the groups "most directly affected" be identified for a given policy? How many representatives of each group will join the relevant council? Will all groups enjoy equal representation, or will those with stronger interests get more representatives? And how will the council make decisions? Will it employ simple majority rule, as Burnheim implies at one point (p. 72)? Or will majorities of the different groups have to concur? Burnheim's reluctance to prescribe a one-size-fits-all institutional proposal to fix our political problems is understandable, but it leaves "demarchy" sounding more like a placeholder than a political system.

Burnheim might respond to this objection by pointing out that demarchy is both a political system and a way of thinking about politics. The latter is more

(c) 2017 Macmillan Publishers Ltd. 1470-8914 Contemporary Political Theory Vol. 17, S1, S26-S29 S27 
fundamental, and it may call for different approaches to the former at different times. What matters above all in a demarchy is not the specific structure of each council but the task with which these councils are charged. This task, according to Burnheim, "would be to distil from public discussion the most acceptable policy in a particular matter" (p. 1). To accomplish this task, Burnheim argues that policy in each area should be crafted by "a representative sample of the legitimate interests most strongly affected by the problem to be solved, but not every group that has an interest in it" (p. 39; see also pp. 5, 6). Under demarchy, "the people to whom the formulation of various policy decisions are entrusted are not a representative sample of the community," i.e., a simple random sample. Rather, the council members "are chosen because they are likely to contribute to sound deliberation" (p. 39).

How does Burnheim envision this "sound deliberation" emerging under demarchy? Basically, Burnheim believes that modern policymaking involves "many conflicting considerations," and that "the best way of resolving the conflict between such different considerations is by discussion of possible compromises and negotiation among those who are differently affected by these considerations" (p. 17). This process of negotiation is not equivalent to simple bargaining between interest groups. For one thing, while the members of Burnheim's councils are selected from the most strongly affected interests, they are not selected as delegates from those interests. Random selection blocks any form of official accountability to the interests from which they come. "A membership chosen by lot without precommitments or any debts to backers who enabled their candidatures can face the issues as they see them on their personal responsibility. The openings for power trading are minimal" (p. 71). This would free up council members to devise creative solutions to policy problems. These solutions would obviously be acceptable to those with the strongest interest in the issue at hand, but they would also be acceptable to the public at large. Because the councils have only proposal power, "their success in getting anything done depends entirely on the general perception of their performance" (p. 73; see also pp. 5, 17-18).

As a story about how politics might be done, Burnheim's account of demarchy is very intriguing. But its radical nature works against the rejection of utopianism that guides talk of institutional design in The Demarchy Manifesto. In the book's preface, Burnheim writes that

The message of this book can be stated quite succinctly. We face problems that call for collective decision on matters of unprecedented importance and difficulty. If we are to have any chance of getting those decisions right, the procedures by which we come to them must be divorced from struggles for political power. There is a way of doing this that can be institutionalised without any exercise of power, just by voluntary organisations (p. vii). 
It is ambitious to imagine that political decision-making might become divorced from political power. It is even more ambitious to imagine that this might be done through organizations capable of leading only through good example. But Burnheim seems not to realize just how herculean a task he is setting for himself in The Demarchy Manifesto. In the end, the way of doing politics that he proposes comes off sounding even more utopian than the few institutional proposals he makes.

"What follows," Burnheim writes in the introduction to The Demarchy Manifesto, "is sketchy. It does not aim to prove anything. It is directed towards getting people to test my proposals in practice" (p. 10). The picture of demarchy offered by Burnheim in the book - both the political system and the way of thinking about politics - is intriguing and worthy of further exploration. But a sketchy manifesto is a contradiction in terms. The Demarchy Manifesto may lead people to think about demarchy, but I doubt it will turn any of them into convinced demarchists.

\section{Acknowledgement}

I would like to thank Huda Awan for valuable research assistance in preparing this review.

\section{References}

Burnheim, J. (1981a). Statistical democracy: An alternative to democratic centralism and communalism. Radical Philosophy, 27, 5-12.

Burnheim, J. (1981b). Statistical democracy: How is a socialist democracy possible? Thesis Eleven, 3(1), $60-71$.

Burnheim, J. (1985). Is Democracy Possible?. Berkeley: University of California Press.

Peter Stone

Trinity College, Dublin 2, Ireland pstone@tcd.ie 